\title{
PERBEDAAN PENAFSIRAN DALAM PENERAPAN HUKUM SEBAGAI KRIMINOGEN DALAM PEMBERANTASAN TINDAK PIDANA NARKOTIKA
}

\author{
Desi Dwi Hariyani \\ S2 Fakultas Hukum Universitas Sebelas Maret \\ E-mail: dwihariyanidesi@gmail.com
}

\begin{abstract}
In Law Number 35 Year 2009 on Narcotics, in practice pose a problem in particular in the application of Article 112, Paragraph (1) and Article 127 Paragraph (1) letter a. The problem occurs because of a lack of clarity in the second chapter of the so in its application lead to differences in interpretation between law enforcement could be kriminogen in the eradication of criminal acts of narcotics. This paper will try to see how a difference of interpretation in the application of the law could be kriminogen in the eradication of criminal acts of narcotics. The research used is research of the doctrinal approach to law. The results of his research is the difference in interpretation between law enforcement in applying Article 112, Paragraph (1) and Article 127 Paragraph (1) letter a produces a verdict that is different between the perpetrators of the deed are almost the same so it is criminal as a treatment to the offender to be less precise. Actors are supposed to be rehabilitated but in the beat, or vice versa. Differences of interpretation also resulted in the increasing amount of legal effort in the case of narcotics that have an impact on the large number of prisoners of narcotics. Both those things can be krimonogen new in the crime of narcotics as the offender can commit a crime repeatedly and learn from other offenders. It is necessary for matching between the perception of law enforcement by doing the interpretation of the profound and more far more needs to be done changes to such Legislation.
\end{abstract}

Keywords : Difference of Interpretation, Kriminogen, Narcotic

Abstrak

Pada undang-undang Nomor 35 Tahun 2009 tentang Narkotika, pada prakteknya menimbulkan sebuah masalah khususnya pada penerapan Artikel 112, Alinea (1) dan Alinea 127 Alinea (1) huruf a. Masalah terjadi karena kurangnya kejelasan pada bab dua tentang pengaplikasiannya sehingga mengakibatkan perbedaan interpretasi antara penegakan hukum bisa menjadi kriminogen dalam penghapusan tindak pidana narkotika. Makalah ini akan mencoba untuk mengetahui bagaimana perbedaan interpretasi dalam penerapan undangundang tersebut dapat menjadi kriminogen dalam penghapusan tindak pidana narkotika. Penelitian yang digunakan adalah penelitian pendekatan doktrinal terhadap hukum. Hasil penelitiannya adalah perbedaan interpretasi antara penegakan hukum dalam penerapan Pasal 112, Alinea (1) dan Pasal 127 Alinea (1) huruf a menghasilkan sebuah putusan yang berbeda diantara para pelaku hamper sama jadi ini adalah kriminal (penjahat) sebagai perlakuan terhadap pelanggar kurang tepat. Para pelaku seharusnya direhabilitasi tetapi dalam irama, atau sebaliknya. Perbedaan interpretasi juga mengakibatkan peningkatan jumlah upaya hukum pada perkara narkotika yang memiliki dampak terhadap sejumlah narapidana narkotika. Kedua hal tersebut bisa jadi merupakan kriminogen yang baru dalam tindak pidana narkotika karena pelanggar dapat melakukan tindak pidana secara berulang-ulang dan belajar dari pelanggar lainnnya. Perlu ada penyesuaian antara persepsi tentang penegakan hukum dengan melakukan interpretasi yang nyata dan yang lebih jauh diperlukan adalah mengubah peraturan perundang-undangan.

Kata kunci: Perbedaan Interpretasi, Kriminogen, Narkotika 


\section{Pendahuluan}

Pemberantasan tindak pidana narkotika pada tataran tertentu merupakan suatu dilema, di satu sisi negara harus tetap menjamin ketersediaan narkotika namun di sisi yang lain negara harus melakukan upaya pemberantasan penyalahgunaan narkotika. Permasalahan tersebut telah diantisipasi dengan penyusunan Undang-Undang Nomor 35 Tahun 2009 tentang Narkotika yang menyatakan bahwa undang-undang tersebut dibentuk sebagai upaya peningkatan pelayanan kesehatan dengan mengusahakan ketersediaan narkotika jenis tertentu yang dibutuhkan sebagai obat serta melakukan pencegahan dan pemberantasan bahaya penyalahgunaan dan peredaran gelap narkotika dan prekursor narkotika.

Undang-Undang Nomor 35 Tahun 2009 mempunyai 2 (dua) sisi yang berbeda. Di satu sisi bersifat humanis dengan adanya kewajiban untuk menjalani rehabilitasi bagi pecandu dan korban penyalahgunaan, tetapi di sisi lain bersifat keras dengan adanya hukuman pidana yang cukup tinggi dan ancaman pidana minimal(http://youthproactive.com/201503/speakup/permasalahan-penyalahgunaan-narkoba-di-indonesia/,diakses pada tanggal 4 Mei 2020 jam 12.15 WIB).

Tindak pidana narkotika memiliki keunikan yaitu crime without victim (kejahatan tanpa korban). Pelaku tindak pidana narkotika juga berperan sebagai korban (Moh. Taufik Makarao, Suhasril, H. Moh Zakky A.S 2003:vii).

Meskipun Undang-Undang Nomor 35 Tahun 2009 tentang Narkotika telah memuat ancaman pidana yang sangat tinggi dan ancaman pidana minimal, ternyata tidak cukup efektif untuk memberantas tindak pidana narkotika.

\section{Tabel 1}

Data Nasional Tindak Pidana Narkotika dan Psikotropika Tahun 2013 - 2017

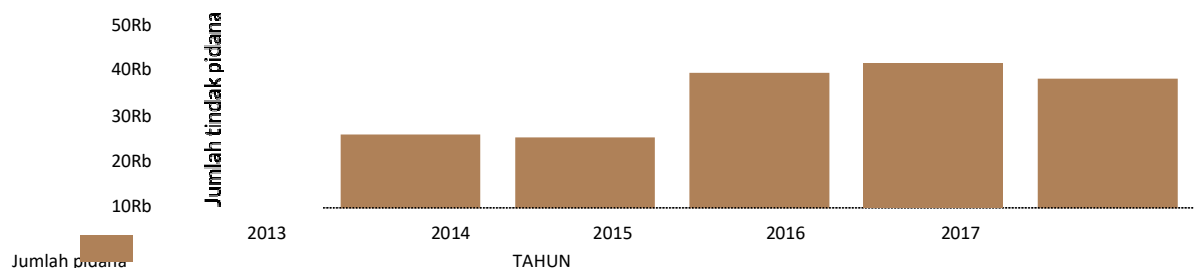

Sumber: Badan Pusat Statisiti https://lokadata.beritagar.id/chart/preview/jumlah-tindak-pidana-narkotika-dan psikotropika-2013-2017-1551694734 
Angka tertinggi tercatat pada 2016 yakni 39.171 tindak pidana atau meningkat 6,49 persen dari tahun 2015. Periode tahun 2018, jumlahnya menurun 10,2 persen dibandingkan tahun sebelumnya, menjadi 35.142 tindak pidana. Statistik kriminalitas pada periode lima tahun terakhir secara keseluruhan tetap saja menunjukkan kecenderungan yang terus meningkat secara signifikan.

Menteri Hukum dan HAM (Menkumham) Yasonna Hamonangan Laoly menyampaikan hampir 50 persen penghuni lembaga pemasyarakatan (lapas) dan rumah tahanan (rutan) merupakan narapidana narkoba (https://nasional. okezone.com/read /2019/ 07/ 25/337/2083589/menkumham-lebih-dari-50-penghuni-lapas-di-indonesia-adalah-napinarkoba, diakses pada tanggal 30 April 2020, jam 11.35 WIB). Jaksa Agung Muda Tindak Pidana Umum menyatakan paling banyak menangani perkara perihal narkotika sepanjang 2019 (https://nasional.kompas.com/read/2019/12/30/16494971/sepanjang-2019-jampidumpaling-banyak-tangani-perkara-narkotika, diakses pada tanggal 4 Mei 2020 jam 11.55 WIB.)

Data perkara yang paling banyak diajukan upaya hukum kasasi ternyata juga perkara narkotika dan psikotropika sebanyak 2715 perkara (60,13\%).(http://patrenggalek.go.id/informasi-pengadilan/271-sepanjang-2019-ma-memeriksa-20-275-perkara diakses pada tanggal 4 Mei 2020 jam 12.05 WIB).

Pelaku tindak pidana narkotika tidak jarang mendapatkan hukuman berdasarkan putusan pengadilan yang kurang memenuhi rasa keadilan dan kepastian hukum. Peristiwa hukum yang sama bisa dituntut atau diputus dengan pasal yang berbeda atau sebaliknya peristiwa hukum yang berbeda dituntut atau diputus dengan pasal yang sama. Hal ini terjadi akibat dari adanya perbedaan penafsiran dari penegak hukum yang perspektifnya berbeda.

Implikasinya pidana yang dijatuhkan kepada pelaku kejahatan narkotika bisa kurang tepat. Kesalahan ini bisa memunculkan kriminogen baru dalam kejahatan narkotika. Pelaku yang seharusnya direhabilitasi tetapi di penjarakan, atau sebaliknya, hal ini bisa menjadi penyebab pelaku melakukan kejahatan berulangkali.

Masalah adalah keadaan yang menimbulkan pertanyaan, sehingga tidak puas hanya melihat saja, melainkan ingin mengetahui lebih dalam (Mohammad Hatta,1990 : 14). Uraian tersebut di atas menimbulkan pertanyaan bagaimana perbedaan penafsiran dalam penerapan hukum bisa menjadi kriminogen dalam pemberantasan tindak pidana narkotika.

Metode penelitian dalam penulisan ini adalah penelitian hukum normatif atau disebut juga penelitian hukum doctrinal (Amiruddin, 2004 :118). Hukum dikonsepkan sebagai apa yang tertulis dalam peraturan perundang-undangan (law in books) atau hukum dikonsepkan 
sebagai kaidah atau norma yang merupakan patokan berperilaku manusia yang dianggap pantas. Pendekatan yang digunakan dalam penulisan ini adalah pendekatan perundangundangan yaitu menganalisa permasalahan yang diangkat dengan peraturan-peraturan yang terkait. (Peter Mahmud Marzuki, $2015: 133$ ).

\section{Pembahasan}

\section{Perbedaan Penafsiran Menjadi Faktor Kriminogen Dalam Pemberantasan Tindak Pidana Narkotika}

Istilah "Narkotika" berasal dari Bahasa Yunani yaitu "narke" yang berarti terbius sehingga tidak merasakan apa-apa (Hari Sasangka, 2003:35). Pada awalnya penggunaan obat-obatan jenis opium atau candu atau madat hanya digunakan sebagai alat bagi upacara ritual keagamaan dan pengobatan (Rush, James R, :3-4. Seiring perkembangan zaman, penyalahgunaan narkotika semakin marak dan semakin membahayakan sehingga dibentuklah peraturan untuk menekan angka penyalahgunaan narkotika yang telah mengalami beberapa kali perubahan sampai pada dibentuknya Undang-Undang Nomor 35 Tahun 2009 tentang Narkotika.

Dalam prakteknya, terdapat beberapa problematika dalam penerapan undang-undang tersebut khusunya berkaitan dengan penerapan Pasal 112 ayat (1) dan Pasal 127 ayat (1) huruf a Undang-Undang Nomor 35 Tahun 2009 tentang Narkotika. Problematika tersebut terlihat dari adanya peningkatan kasus narkotika yang mengajukan upaya hukum sehingga berdampak pada dominasi jumlah tahanan perkara narkotika di Lembaga Pemasyarakatan. Dengan banyaknya jumlah tahanan narkotika dan semakin lamanya tahanan narkotika berinteraksi maka antar tahanan bisa saling mempengaruhi yang berakibat peningkatan kualitas pelakunya, yang semula hanya sebagai pengguna bisa naik kelas menjadi pengedar. Sebenarnya upaya hukum adalah hak yang diberikan oleh undang-undang, tetapi apabila dicermati secara seksama ternyata upaya hukum yang diajukan dalam penanganan tindak pidana narkotika adalah dikarenakan adanya perbedaan penafsiran antara penegak hukum baik itu Penuntut Umum, Penasehat Hukum, bahkan Hakim pada tiap tingkatan dimana antara Hakim tingkat pertama bisa berbeda dengan Hakim pada tingkat banding maupun kasasi. Hal ini dapat dilihat dari adanya putusan yang berbeda pada beberapa perkara dengan kasus posisi yang sama berkaitan dengan penerapan pasalnya.

Perbedaan penerapan pasal tersebut menunjukkan adanya perbedaan penafsiran hukum. Perbedaan penafsiran hukum sebenarnya merupakan hal yang wajar dalam proses 
peradilan, namun permasalahannya adalah dengan beragamnya penafsiran hukum mengasumsikan kualitas peraturan perundang-undangan tersebut kurang baik atau setidaknya tidak dapat memberikan kepastian hukum yang merupakan orientasi dari tujuan hukum sebagaimana yang diungkapkan oleh Gustav Radbruch (Krisnajadi, 1989:.60). Kepastian hukum tidak terwujud dengan sendirinya tetapi masih harus diterapkan oleh penegak hukum, untuk itu diperlukan suatu kepastian hukum pada penerapannya dalam hal ini hukum positif. Tetapi makna hukum yang kabur bisa melemahkan hukum positif tersebut (Sobandi Handy,2011: 82-83). Konsekuensi dari prinsip nullum crimen nulla poena sine lege scripta (tiada pidana tanpa ada undang-undang yang mengaturnya) adalah perbuatan yang dilarang harus tertulis jelas dalam undang-undang (Eddy OS Hiariej, 2009 :.4-5. Prinsip tersebut yang sering disebut sebagai azas legalitas yang berfungsi untuk melindungi rakyat dari pelaksanaan kekuasaan yang tanpa batas dari pemerintah dengan menggunakan hukum pidana sebagai sarananya, pendapat Schafmeister inilah yang dapat dikatakan bahwa undangundang pidana memiliki fungsi sebagai perlindungan(Schaffmeister (et al), diedit oleh JE. Sahetapy, 2004:.4).

Soerjono Soekanto menyatakan bahwa antara kepastian hukum dan keadilan adalah dua faktor yang saling menunjang dalam upaya menjaga keserasian antara kepentingankepentingan yang terdapat di dalam masyarakat (Rato, Dominikus : 2014). Adanya perbedaan penafsiran oleh penegak hukum yang disebabkan oleh ketidakjelasan (kabur) hukum positif berupa Undang-Undang Nomor 35 Tahun 2009 tentang Narkotika, mengakibatkan hukum tersebut menjadi lemah dan menimbulkan ketidakpastian sehingga bisa mengakibatkan ketidakadilan.

Menurut Diah Imaningrum Susanti, salah satu perkembangan yang paling menarik di dalam teori hukum saat ini adalah semakin pentingnya konsep interpretasi (Diah Imaningrum Susanti, 2019 : 22). Ajaran interpretasi dalam penemuan hukum ini sudah lama dikenal, yang disebut dengan hermeneutika yuridis (Bambang Sutiyoso, 2009 : 82).

Menurut Peter Goodrich, isu-isu penafsiran hukum mempersoalkan isu bahasa dan interpretasi, teks dan signifikasi melalui makna yang diberikan, mulai dari pertanyaan institusional, aksiologis, sosial politik, sampai dengan pertanyaan analitik tentang metode penafsiran mana yang paling memadai (Bambang Sutiyoso,2009:83). Menurut Diah, berdasarkan isu-isu penafsiran hukum tersebut terdapat tiga masalah penting dalam undangundang itu yaitu maksud, kekaburan dan kompleksitas. Berdasarkan hal tersebut, ketidakjelasan Undang-Undang Nomor 35 Tahun 2009 tentang Narkotika khususnya Pasal 112 Ayat (1) dan Pasal 127 Ayat (1) huruf a bisa dilihat dari : 


\section{Maksud (Intentions)}

Menentukan maksud sebuah teks pasal dalam ketentuan pidana bukanlah merupakan sesuatu yang mudah mengingat terdapat rentang waktu dan jarak antara pembuat undang-undang (Dewan Perwakilan Rakyat) sebagai penyampai pesan dengan pelaksana undang-undang (penegak hukum) sebagai penerima pesan. Terlebih para anggota DPR yang tergabung dalam sebuah partai politik mempunyai ideologi masingmasing yang pada saat membuat undang-undang mempunyai maksud dan tujuan sesuai dengan garis ideologi politiknya.

Kesulitan selanjutnya para aparat penegak hukum dalam proses persidangan mempunyai kepentingan yang berbeda antara Penuntut Umum dengan Penasihat Hukum atau terdakwa dan hakim. Penuntut Umum sudah barang tentu akan menafsirkan teks undang-undang sesuai dengan kepentingan pembuktian perkara dan sebaliknya Penasihat Hukum sesuai kepentingannya dalam rangka pembelaan terdakwa. Di sisi yang lain hakim akan menafsirkan maksud undang-undang sesuai keyakinannya.

Pasal 112 Ayat (1) Undang-Undang Nomor 35 Tahun 2009 tentang Narkotika dengan unsur "Setiap orang yang tanpa hak atau melawan hukum memiliki, menyimpan, menguasai atau menyediakan Narkotika Golongan I bukan tanaman."Frase“memiliki, menyimpan, menguasai atau menyediakan" sebagai unsur pokok yang hendak dituju dari pasal tersebut mempunyai cakupan peristiwa atau perbuatan yang dimensinya sangat luas. Akibatnya banyak peristiwa atau perbuatan yang dengan mudah dapat terjaring oleh maksud dari ketentuan tersebut.

Bagi Penuntut Umum demi kepentingan pembuktian tentu sangat "menguntungkan" karena perbuatan pelaku mudah untuk dibuktikan, sebaliknya akan sangat "merugikan" bagi Penasihat Hukum atau terdakwa karena akan menyulitkan untuk melakukan pembelaan. Permasalahan sesungguhnya bukanlah pada rugi atau untungnya para pihak tetapi akan sangat menyulitkan bagi aparat penegak hukum untuk dapat menyeimbangkan antara kepastian, kemanfaatan dan keadilan.

Pasal 127 ayat (1) huruf a Undang-Undang Nomor 35 Tahun 2009 tentang Narkotika dengan unsur "Setiap penyalah guna Narkotika Golongan I bagi diri sendiri”. Perbuatan "Penyalah Guna" mempunyai maksud pada peristiwa menggunakan atau mengkonsumsi narkotika yang dilakukan tanpa hak atau melawan hukum dalam hal ini tanpa rekomendasi dokter.

2. Kekaburan (Vagueness) 
Menurut HLA. Har (Bambang Sutiyoso,2009: 25-26) permasalahan kekaburan ketentuan perundang-undangan meliputi :

Pertama, dalam komunitas yang luas, hukum bekerja melalui aturan-aturan umum dan bukan melalui arahan-arahan individual, maka ia cenderung bersifat abstrak, menggunakan konsep-konsep yang umum, sehingga mungkin menjadi kabur. Kedua, karena aturan hukum menggunakan bahasa untuk menyelesaikan konflik sosial, banyak yang bergantung pada kata-kata yang digunakan oleh aturan-aturan ini. Ketentuan peraturan perundang-undangan sesungguhnya mempunyai dua lapisan yaitu teks hukum yang tertulis dan norma hukum yang tidak secara eksplisit tertulis tetapi maknanya berada dibalik teks hukum tersebut.

Pasal 112 Ayat (1) Undang-Undang Nomor 35 Tahun 2009 tentang Narkotika tingkat kekaburannya terletak pada makna teks yang sangat luas sehingga banyak mencakup realitas perbuatan. Akibatnya banyak perbuatan yang terjaring dengan teks hukum tersebut. Hal ini sangat rawan untuk mengkriminalkan perbuatan seseorang, sehingga asas keadilan sulit untuk ditegakkan dan akan terjebak pada kepastian hukum.

Pasal 127 Ayat (1) huruf a Undang-Undang Nomor 35 Tahun 2009 tentang Narkotika dari segi aturan yang bersifat umum dan dari segi teks hukum lebih jelas dan lebih spesifik maknanya. Hubungan norma hukum dan teks hukumnya lebih mudah dipahami oleh seseorang terutama aparat penegak hukum sehingga dalam penerapannya tidak begitu memerlukan penafsiran hukum yang rumit.

3. Kompleksitas

Menurut Julies L. Coleman dan Brian Leiter (Bambang Sutiyoso,2009:32). kompleksitas peraturan perundang-undangan akan lebih rumit jika beberapa aturan itu berkonflik satu sama lain, dalam situasi seperti ini hukum menjadi tidak pasti dan interpretasi berhenti menjadi obyektif. Menurut Emanuela Carbonara dan Fransesco Parisi (Bambang Sutiyoso,2009: 32), menyatakan bahwa harmonisasi hukum dari berbagai peraturan yang berkonflik justru menimbulkan disharmoni.

Pasal 112 Ayat (1) dengan Pasal 127 Ayat (1) huruf a Undang-Undang Nomor 35 Tahun 2009 tentang Narkotika, telah terjadi konflik norma yang dapat menimbulkan kompleksitas permasalahan ketika diterapkan pada kasus konkret. Konflik akan terjadi karena perbuatan pelaku "Penyalah Guna" pada saat yang bersamaan hampir selalu disertai dengan perbuatan "memiliki, menyimpan, menguasai atau menyediakan". Oleh karena itu ketika menghadapi kasus konkret aparat penegak hukum dituntut untuk 
melakukan penafsiran hukum secara arif dan bijaksana, untuk menentukan peristiwa pidana apa, yang sesungguhnya dilakukan oleh pelaku tindak pidana.

Konsep hukum menurut Soetandyo Wignjosoebroto diantaranya bahwa hukum adalah norma-norma positif di dalam sistem perundang-undangan hukum nasional dan juga hukum adalah apa yang diputuskan oleh hakim in concerto, tersistematisasi sebagai judge made law (https://kelashukum.com/2019/10/19/tujuan-hukum-pidana/, diakses pada tanggal 4 Mei 2020 jam 14.30 WIB.)

Hukum sebagai norma positif dalam tindak pidana narkotika terdapat dalam UndangUndang Nomor 35 Tahun 2009 tentang Narkotika. Peraturan lain berkaitan dengan undangundang tersebut adalah Surat Edaran Mahkamah Agung Nomor 04 Tahun 2010 tentang Penempatan Penyalahgunaan, Korban Penyalahgunaan dan Pecandu Narkotika ke dalam Lembaga Rehabilitasi Medis dan Rehabilitasi Sosial, sebagai pedoman hakim dalam penerapan pemidanaan rehabilitasi yang hanya dapat dijatuhkan pada klasifikasi tindak pidana pada saat tertangkap tangan ditemukan barang bukti pemakaian 1 (satu) hari dalam hal ini sejumlah maksimal satu gram. Selain itu terdapat juga Surat Edaran MA Nomor 1 Tahun 2017 tentang Pemberlakuan Rumusan Hasil Rapat Pleno Kamar Mahkamah Agung Tahun 2017 sebagai Pedoman Pelaksanaan Tugas bagi Pengadilan yang berisi diantaranya dalam hal terdakwa tidak tertangkap tangan sedang memakai narkotika dan pada diri terdakwa ditemukan barang bukti narkotika yang jumlahnya/beratnya relatif sedikit serta hasil tes urine terdakwa positif mengandung metamphetamine, namun Penuntut Umum tidak mendakwakan Pasal 127 Ayat (1) Undang-Undang Nomor 35 Tahun 2009 tentang Narkotika maka perbuatan terdakwa tersebut dikategorikan sebagai Penyalahguna Narkotika bagi diri sendiri sebagaimana dalam Pasal 127 Ayat (1) huruf a.

Meskipun dalam Pasal 8 Undang-Undang Nomor 12 Tahun 2011 tentang Pembentukan Peraturan Peundang-undangan disebutkan "peraturan yang ditetapkan Mahkamah Agung termasuk jenis peraturan perundang-undangan yang diakui keberadaannya dan mempunyai kekuatan hukum mengikat sepanjang diperintahkan oleh Peraturan Perundang-undangan yang lebih tinggi atau dibentuk berdasarkan kewenangan." Dalam prakteknya, SEMA tersebut belum dijadikan dasar dalam penegakan hukum tindak pidana narkotika khususnya bagi aparat penegak hukum di luar Mahkamah Agung, bahkan tidak jarang di lingkungan Mahkamah Agung sendiri antara pengadilan tingkat pertama dan kedua mempunyai penafsiran yang berbeda dan tidak mendasarkan pada SEMA tersebut sehingga terhadap perkara narkotika banyak yang melakukan upaya hukum. Tidak jarang Mahkamah Agung sendiri dengan mendasarkan pada SEMA tersebut, memutus perkara narkotika hanya HPE. Vol. 8 No.1 Jan- Juni 2020 
berdasarkan jumlah narkotika yang dikuasai pelaku, tidak mendasarkan pada kasus posisi perkaranya atau profile pelaku sehingga tidak jarang antara putusan yang satu dengan yang lain berbeda dan kurang memenuhi rasa keadilan dan kepastian hukum bagi pelaku maupun bagi masyarakat.

Pasal 112 Ayat (1) yang menyebutkan seseorang tanpa hak atau melawan hukum memiliki, menyimpan, menguasai, atau menyediakan Narkotika Golongan I, seyogyanya diikuti dengan tujuan atau fakta hukum untuk kepentingan apa sehingga dengan adanya kejelasan tersebut tidak menimbulkan multi tafsir dan tidak digunakan sebagai pasal cadangan karena sebenarnya beberapa pasal dalam UU Narkotika ini terdapat unsur memiliki, menyimpan, menguasai, sehingga bisa dikenakan terhadap semua perbuatan (Ratna WP, 2017:23).

Menurut Hans Kelsen, keadilan dapat dimaknai sebagai legalitas. adalah adil jika suatu aturan diterapkan pada semua kasus dimana menurut isinya memang aturan tersebut harus diaplikasikan. Adalah tidak adil jika suatu aturan diterapkan pada satu kasus tetapi tidak pada kasus lain yang sama (Jimly Asshiddiqie, M. Ali Safaat,2012:15). Dengan adanya perbedaan penerapan hukum dari beberapa perkara narkotika yang menghasilkan putusan yang berbeda-beda dengan kasus yang sama bisa memunculkan ketidakadilan. Keadaan ini bisa menimbulkan ketidakjelasan yang berujung kepada ketidakpastian dan ketidakadilan. Beberapa putusan dianggap mengusik rasa keadilan masyarakat, juga telah mengikis kepercayaan terhadap peradilan pada umumnya (Poentang Moerad, 2005:6).

Adanya perbedaan putusan tersebut berimplikasi pada penerapan pemidanaannya. J.D. Mabbot, memandang seorang "penjahat" sebagai seseorang yang telah melanggar suatu hukum, walaupun sebenarnya ia bukan orang jahat. Artinya, jahat atau tidak jahat, bila seseorang telah bersalah melanggar hukum, maka orang itu harus dipidana (M. Sholehuddin, 2003:68-69). Salah satu alternatif upaya pemberantasan penyalahgunaan narkotika adalah keseimbangan pemidanaan dengan konsep pemulihan atau rehabilitasi terhadap pelaku penyalahgunaan narkotika. Pada tahun 1998, dalam sesi khusus Sidang Majelis Umum PBB dikeluarkanlah Political Declaration on Countering The World Drugs Problem 1998 mengenai asas-asas demand reduction narkotika (Anang Iskandar, 2018:5). Keseimbangan langkah inilah yang dijadikan dasar oleh negara-negara peserta sidang dalam mengambil langkah mengatasi permasalahan narkotika dengan penekanan akan pentingnya upaya pencegahan, perawatan terhadap penyalahguna narkotika dan upaya pemberantasan terhadap peredaran gelap narkotika (Anang Iskandar, 2018: 6). 
Indonesia sebagai negara yang mengadopsi Konvensi Tunggal Narkotika 1961 beserta protokol yang mengubahnya, mengacu pada prinsip-prinsip Political Declaration and Plan of Action of 2009, dalam kebijakan penanganan narkotika dengan menggunakan Balance Approach antara demand reduction dan supply reduction (Anang Iskandar,2018:7). Indonesia yang telah menerbitkan Undang-Undang Nomor 35 Tahun 2009 tentang Narkotika sebenarnya secara yuridis normatif telah menganut pendekatan yang seimbang yaitu rehabilitasi untuk pecandu dan korban penyalahguna, serta pidana penjara untuk penyalahguna narkotika.

Karena Indonesia telah meratifikasi konvensi PBB hasil sidang tahun 1998, dimana para penyalah guna diberikan alternatif berupa rehabilitasi, maka Undang-Undang Narkotika kita mengatur double track system yaitu sanksi pidana dan sanksi tindakan (Yasonna H. Laoly, 2019). dalam hal ini rehabilitasi. Double track system dalam perumusan sanksi terhadap tindak pidana penyalahgunaan narkotika dianggap paling tepat, karena berdasarkan tinjauan viktimologi bahwa pecandu narkotika adalah victiming victim yaitu korban sebagai pelaku (Yasonna H. Laoly, 2019: 132).

Rehabilitasi senada dengan tujuan pemidanaan yaitu teori treatment dan teori social defence. Treatment sebagai tujuan pemidanaan dikemukakan oleh aliran positif. Aliran ini beralaskan paham determinasi yang menyatakan bahwa orang tidak mempunyai kehendak bebas dalam melakukan suatu perbuatan karena dipengaruhi oleh watak pribadinya, faktorfaktor lingkungan maupun kemasyarakatannya (Muladi dan Barda Nawawi,1992:12). Rehabilitasi terhadap pecandu narkotika menganut teori treatment yang sebab rehabilitasi terhadap pecandu narkotika merupakan suatu proses kegiatan pengobatan secara terpadu untuk membebaskan pecandu dari ketergantungan. Treatment sebagai tujuan pemidanaan sangat pantas diarahkan pada pelaku kejahatan, bukan pada perbuatannya (Teguh Prasetyo dan Abdul Halim Barkatullah, 2005: 95-96). Pemidanaan yang dimaksudkan pada aliran ini adalah untuk memberi tindakan perawatan (treatment) dan perbaikan (rehabilitation) kepada pelaku kejahatan sebagai pengganti dari penghukuman. Pelaku kejahatan adalah orang yang sakit sehingga membutuhkan tindakan perawatan (treatment) dan perbaikan (rehabilitation)( C. Ray Jeffery dalam Mahmud Mulyadi, :79). Rehabilitasi bagi narapidana di lembaga pemasyarakatan adalah tempat yang memberikan pelatihan ketrampilan dan pengetahuan untuk menghindarkan diri dari narkotika (http://repository.umy.ac.id/bitstream/handle/123456789/5009/BAB\%20III.pdf?sequence=7 \&isAllowed=y), diakses pada tanggal 3 Juni 2020 jam 11.00 WIB.) 
Kebijakan untuk menempatkan penyalah guna pada lembaga rehabilitasi melalui proses asesmen tanpa persidangan formal adalah bentuk depenalisasi terhadap tindak pidana narkotika dimana penyalah guna, korban, dan pecandu yang pada awalnya dijatuhi sanksi pidana diganti dengan rehabilitasi (Supardi. http/www.bnn.go.id/konten, Diunduh pada tanggal 25 Maret 2018 pukul 09.32 WIB). Dengan adanya penjatuhan hukuman yang tepat bagi pelaku tindak pidana narkotika diharapkan bisa mengurangi bahkan memberantas penyalahgunaan narkotika dan tujuan hukum untuk keadilan, kepastian, dan kemanfaatan bisa tercapai. Untuk itu diperlukan persamaan persepsi antar penegak hukum dalam penerapan hukum tindak pidana narkotika khususnya Pasal 112 Ayat (1) dan Pasal 127 Ayat (1) huruf a Undang-Undang Nomor 35 Tahun 2009 tentang Narkotika sehingga tidak menimbulkan penafsiran yang berbeda yang berakibat pada banyaknya perkara narkotika yang mengajukan upaya hukum dan dengan treatment yang tepat bagi pelakunya bisa mengurangi angka kejahatan narkotika.

\section{Kesimpulan}

Undang-Undang Nomor 35 Tahun 2009 tentang Narkotika sebagai hukum positif dalam pemberantasan tindak pidana narkotika pada prakteknya menimbulkan permasalahan khususnya dalam penerapan Pasal 112 Ayat (1) dan Pasal 127 Ayat (1) huruf a. Adanya ketidakjelasan dalam kedua pasal tersebut menyebabkan terjadinya perbedaan penafsiran antar penegak hukum sehingga menghasilkan putusan yang berbeda-beda antara pelaku yang satu dengan pelaku yang lain dengan perbuatan yang sama. Implikasinya treatment atau pidana yang dijatuhkan kepada pelaku kejahatan narkotika kurang tepat antara pidana rehabilitasi atau pidana penjara yang kemudian memunculkan faktor krimonogen baru dalam kejahatan narkotika. Pelaku yang seharusnya direhabilitasi tetapi di penjarakan, atau sebaliknya pelaku yang seharusnya dipenjara tetapi justru direhabilitasi, hal ini salah satu penyebab seorang pelaku melakukan kejahatan berulangkali. Selain itu perbedaan penafsiran tersebut juga mengakibatkan meningkatnya upaya hukum dalam perkara narkotika yang juga berdampak pada dominasi jumlah tahanan narkotika di Lembaga Pemasyarakatan. Dengan banyaknya jumlah tahanan narkotika dan semakin lamanya tahanan narkotika berinteraksi maka antar tahanan bisa saling mempengaruhi yang berakibat peningkatan kualitas pelaku, yang semula hanya sebagai pengguna bisa naik kelas menjadi pengedar dan hal ini bisa menjadi kriminogen baru dalam pemberantasan tindak pidana narkotika. Untuk itu ke depan perlu dilakukan penyamaan persepsi antar penegak hukum dengan melakukan penafsiran yang mendalam berkaitan dengan penerapan Pasal 112 Ayat (1) dan Pasal 127 Ayat (1) huruf 
a Undang-Undang Nomor 35 Tahun 2009 tentang Narkotika dan lebih jauh lagi perlu dilakukan perubahan terhadap Undang-Undang tersebut.

\section{Daftar Pustaka}

Amiruddin, dkk.,2004, Pengantar Metode Penelitian Hukum, Jakarta, Rajawali Pers.

Anang Iskandar, 2018, Penegakan Hukum Narkotika, Jakarta, PT Elex Media Komputindo

Bambang Sutiyoso, 2009, Metode Penemuan Hukum (Upaya Mewujudkan Hukum Yang Pasti dan Berkeadilan), Cetakan Ketiga, Yogyakarta UII Press.

C. Ray Jeffery dalam Mahmud Mulyadi, Criminal Policy, Pendekatan Integral Penal Policy dan Non-Penal Policy dalam Penanganan Kejahatan Kekerasan, Medan, Pustaka Bangsa Press.

Diah Imaningrum Susanti,2019, Penafsiran Hukum Teori dan Metode, Jakarta, Sinar Grafika

Hari Sasangka, 2003, Narkotika dan Psikotropika Dalam Hukum Pidana, Bandung, Mandar Maju.

.Jimly Asshiddiqie, M. Ali Safaat, 2012, Teori Hans Kelsen tentang Hukum, Jakarta, Konstitusi Press (Konpress).

Mohammad Hatta, 1990, Pengantar ke Jalan Ilmu Pengetahuan, Jakarta, Mutiara.

Moh. Taufik Makarao, Suhasril, H. Moh Zakky A.S.,2003.Tindak Pidana Narkotika, Jakarta, Ghalia Indonesia.

Muladi dan Barda Nawawi, 1992, Bunga Rampai Hukum Pidana, Bandung, Alumni.

M. Sholehuddin, 2003, Sistim Sanksi Dalam Hukum Pidana, Ide dasar Double Track System dan Implementasinya, Jakarta, Penerbit PT. Rajagrafindo Persada.

Yasonna H. Laoly,2019, Jerat Mematikan Perspektif Kesejahteraan Ekonomi dalam Penyalahgunaan Narkotika, Tengerang Selatan, PT Pustaka Alvabet.

Poentang Moerad, 2005, Pembentukan Hukum Melalui Putusan Pengadilan dalam Perkara Pidana, Bandung, Alumni.

Peter Mahmud Marzuki, 2015, Penelitian Hukum, revisi ed Jakarta, Prenadamedia Group.

Rato, Dominikus. 2014, Filsafat Hukum Suatu Pengantar Mencari, Menemukan, dan Memajami Hukum, 4th ed Surabaya: LaksBang Justitia.

Ratna WP, 2017, Aspek Pidana: Penyalahgunaan Narkotika Rehabilitasi Versus Penjara, Yogyakarta, Legality.

Rush, James R. Opium to Java: Jawa dalam Cengkraman Bandar-Bandar Opium Cina, Indonesia Kolonial 1860-1910, Yogyakarta, Mata Bangsa

Teguh Prasetyo dan Abdul Halim Barkatullah, 2005. Politik Hukum Pidana (Kajian Kebijakan Kriminalisasi dan Dekriminalisasi), Jakarta, Pustaka Pelajar.

http://youthproactive.com/201503/speak-up/permasalahan-penyalahgunaan narkoba-diindonesia/, diakses pada tanggal 4 Mei 2020 jam 12.15 WIB.

https://lokadata.beritagar.id/chart/preview/jumlah-tindak-pidana-narkotika-dan psikotropika2013-2017-1551694734 
https://nasional.okezone.com/read/2019/07/25/337/2083589/menkumham-lebih dari-50penghuni-lapas-di-indonesia-adalah-napi-narkoba, diakses pada tanggal 30 April 2020, jam 11.35 WIB.

https://nasional.kompas.com/read/2019/12/30/16494971/sepanjang-2019-jampidum-palingbanyak-tangani-perkara-narkotika, diakses pada tanggal 4 Mei 2020 jam 11.55 WIB.

http://pa-trenggalek.go.id/informasi-pengadilan/271-sepanjang-2019-ma-memeriksa-20-275perkara diakses pada tanggal 4 Mei 2020 jam 12.05 WIB.

http://repository.umy.ac.id/bitstream/handle/123456789/5009/BAB\%20III.pdf?sequence=7\& isAllowed=y), diakses pada tanggal 3 Juni 2020 jam 11.00 WIB.

Buku Register Perkara Tahap Penuntutan Seksi Tindak Pidana Umum Kejaksaan Negeri Karanganyar.

Supardi. "Pro dan Kontra Pidana Mati terhadap Tindak Pidana Narkoba", http/www.bnn.go.id/konten, Diunduh pada tanggal 25 Maret 2018 pukul 09.32 WIB.

https://kelashukum.com/2019/10/19/tujuan-hukum-pidana/, diakses pada tanggal 4 Mei 2020 jam 14.30 WIB. 